A previously stable, 42-year-old housewife of above average intelligence had what appears to have been a prolapsed lumbar disk in April 1962 Manipulative treatment was unsuccessful and she suffered considerable lumbar and sciatic pain In August 1963 she was prescribed Palfium (dextromoramide) and within four months had become addicted to this drug with the usua symptoms of increasing tolerance, increasing consumption, and withdrawal symptoms when she was unable to obtain further supplies. In December 1963 her general practitioner felt that it was essential to discontinue the drug, whereupon she became agitated and suicidally depressed. She was admitted urgently to this hospital and treated symptomatically with Melleril (thioridazine hydrochloride) and vita mins. On this regimen she improved within 72 hours and was fit enough for discharge afte three weeks. Since that time she has shown a mild, fluctuating depressive syndrome which is still requiring treatment. Her backache has been completely relieved with the aid of a surgical corset.

-I am, etc.,

West Cumberland Hospital,

A. W. Drummond.

Whitehaven,

SIR,-Dr. B. A. M. Thompson (31 October, p. 1136) rightly reports a case of addiction (drug dependence) to Palfium (dextromoramide), suggesting that such cases are rare. Twenty-three, in fact, were known to the Home Office at the time of their last report $1-3.6 \%$ of all cases: 15 of the 23 were solely dependent on dextromoramide. It is the increasing dependence on mixtures of all kinds that are chiefly illegal in origin and so giving cause for anxiety, ${ }^{2}$ but this fact should not divert attention from the risk of causing a drug dependence even in therapeutic situations: even the newer analgesics are-predictably-dangerous in this respect. - I am, etc.

Department of Pharmacology,
The London Hospital Medical College C. R. B. Joyce.

REFERENCES

1 Report to the United Nations on the Working of the International Treaties on Narcotic Drugs, London. 2 Lancet, 1964, 1, 649

\section{Diet and Dental Disease}

SIR,-The negative attitude to the prevention of dental caries revealed in your leading article "Diet and Dental Disease" in the issue of 17 October, p. 964, calls for comment. The gist of the article, as I read it, was :

(1) The import of refined carbohydrates to Ghana has greatly increased in recent years.

(2) Professor A. B. Macgregor in an epidemiological study of dental caries in that country found a generally lower incidence than is found in Europe or America, but a relatively high incidence in more wealthy Ghanaians who could afford to consume the imported refined carbohydrates.

(3) It is expected that soon the whole population will be eating white flour and refined sugar rather than unrefined, indigenous cereals; therefore dental caries will soon become in Ghana the scourge which it is in this country.
(4) Therefore, to meet the situation, a "crash programme" for training African dentists is urgently necessary.

This strikes me as being a counsel of despair. Would it not be infinitely more sensible for the Ghanaians to spare themselves the ravages of widespread dental caries (which no dental service in the world could prevent) by halting the import of refined carbohydrate and expanding the production of their indigenous foods ? Especially as rotten teeth are not the only consequence of eating refined sugar and flour.

In the light of present knowledge it is probable that obesity, anaemia, constipation, diabetes, peptic ulcer, degenerative arterial disease, including hypertension and coronary thrombosis, will follow an increasing intake of these refined foods. A recent article by Dodd, ${ }^{1}$ reporting the virtual absence of varicose veins among Zulus living under tribal conditions, confirms the earlier work by Cleave, ${ }^{2}$ who showed that varicose veins could be caused by the colonic stasis of people who had to rely on excessive quantities of refined carbohydrate for their cereals.

Whatever the present state of nutrition or health of the Ghanaian people, long-term improvement is unlikely if indigenous unprocessed carbohydrate is to be replaced by white flour and sugar. For the less advanced nations to "import" the degenerative diseases of Europe and America seems a strange way to " advance." $-\mathrm{I}$ am, etc.,

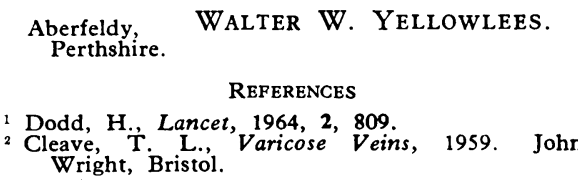

SIR,-90,000 British children, conceived, begotten, and raised in the glow of the Welfare State, will leave school this year with a full set of dentures (cost $£ 500,000) 40$ years too soon. Dental disease, coronary thrombosis, peptic ulcer, diabetes, ulcerative colitis, diverticulitis, piles, hernia, and varicose veins abound in Westernized communities. They progress in lands actually flowing with " milk and honey." They are almost unknown amongst those living in a tribalized way in impoverished territories, but when these people are absorbed into industrialized communities-e.g., the coloured in U.S.A. and the Indians in South Africa-they develop these ailments. Superficially, some of them are explained by blaming nicotine and the stress of present-day living, in spite of clean food, water, improved housing and sanitation, transport and clothing, and shorter working hours.

Our medical profession and health services have never been so large, so well trained, organized, or so reasonably equipped as now, nor our auxiliary services so good or extensive. Yet they are inadequate. The alarm of an impending shortage of nurses and doctors is ringing. The clamour is for an all-round increase. But is this the remedy ?

If these diseases are due to Westernized customs and especially to what we eat, as propounded by Cleave, Yudkin, McCarrison and others, and if white bread and white sugar be a large cause-there is evidence pointing to this-then a return to unprocessed foods, wholemeal bread, and the minimum of brown sugar would be a substantial (literally and metaphorically) preventive. If so, it would be a negligible monetary price to pay for a priceless benefit. But not quite costless. We would have to urge, persuade, and cajole their necessity, especially in high places, day in day out, until public demand exacted $100 \%$ wheaten bread, and taxed white bread and white sugar as heavily as nicotine and alcohol. The battle with big business would rage. Will we sustain it? We would not be friendless: a sturdy nucleus inside and outside of the profession is ready to march with us. Lord Woolton's milk for babies and schoolchildren eliminated rickets. Who will be our John Wesley in a national natural food revival ? With the above diseases even halved, Britain could again export a way of living instead of as now resigning our commitments and declining opportunities of creative services to needful peoples.-I am, etc.,

London $\mathbb{W} .1$.

HAROLD DODD.

\section{Out-patient Prescriptions}

SIR,-The letter by Dr. John H. Swan (31 October, p. 1139) calls for a firm reply. The responsibility for treating a patient belongs to the patient's own doctor, except after admission to hospital, when the responsibility is the consultant's. Apart from the use of special techniques, apparatus, and hospital facilities, it is for the consultant to advise treatment when asked by the practitioner to do so, not to give it. Except when immediate treatment is needed for the patient, I have always refused to use the hospital dispensary for outpatients ; I have always written to the practitioner suggesting treatment. Very occasionally patients have come back to me saying that their doctor had refused to prescribe the treatment I had recommended. My reply has always been, " $\mathrm{He}$ is your doctor, I advise you to do what he says."-I am, etc.,

$$
\text { London W.1. }
$$$$
\text { E. Lipman Cohen. }
$$

SIR,-If essential treatment for his patient be delayed by a general practitioner's obstructive tactics whom does it profit? Do the patients of Dr. John Swan (31 October, p. 1139) find their way to hospital clinics without his knowledge?

The Dean of Westminster drew attention to the fact that doctors no longer swear by Apollo upon graduation (B.M.F., 24 October, p. 1062). Many of us do sign the updated Hippocratic derivative-namely, the Declaration of Geneva, as composed by the World Medical Association in 1948..$^{1}$ Incidentally, it would be interesting to know the proportion of British medical graduates who do sign the declaration, in which is the unequivocal statement, "The health of my patient will be my first consideration" (my italics).

How many doctors in general practice find a lowering of status in co-operating with hospital colleagues in treating the individual patient-our raison d'être? The hospital pharmacy, if extant, may not be able to supply a particular preparation. As the nation has to pay eventually, whatsoever the source of the prescription, do let us bury this hatchet and hang status!- I am, etc.,

Fareham, Hampshire.

W. J. O'ConNell.

\section{RBFERENCE}

${ }^{1}$ European Community, July 1964 